\title{
Sex ratio of apollo butterfly Parnassius apollo (Lepidoptera: Papilionidae) - facts and artifacts
}

\author{
PAWEL ADAMSKI \\ Institute of Nature Conservation PAS, Al Mickiewicza 33, 31-120 Kraków, Poland; adamski@iop.krakow.pl
}

Key words. Apollo butterfly, sex ratio, mark-recapture, activity, effective population size

\begin{abstract}
The adult sex ratio among the genus Parnassius is usually strongly male biased and close to $2: 1$. This paper presents the results of comparative studies, on the basis of data from wild and captive reared populations of apollo butterfly in the Pieniny National Park (Western Carpathians, Poland). Sex ratio among the wild population is strongly male biased and close to $2: 1$, whereas there was no sex ratio bias among the captive population. However, among the captive individuals caught after releasing into the wild, males significantly outnumbered females. There was a significant, sex-related, difference in activity pattern recorded in the field studies: while the majority of females were observed sitting, males were usually flying. This result suggests that the observed sex ratio shifting is at least partially an artifact caused by the more cryptic behaviour of females. The sex ratio bias was more pronounced in the wild population than in captive individuals caught after releasing into wild, which suggests that difference in detectability between the sexes is not the only reason for males outnumbering females.
\end{abstract}

\section{INTRODUCTION}

Population viability analysis is an objective tool used in nature conservation projects for determining the level of endangerment and need for conservations activity (McCarthy et al., 1994; Caughley \& Gunn, 1996). Proper estimation of the population status demands the knowledge of several parameters. One parameter of importance is the effective population size, which is strongly influenced by the sex ratio (Reed et al., 2003; Schtickzelle et al., 2003). Among diploid, non-social insect sex ratio is very often significantly male biased, although this phenomenon is somewhat controversial (Takamura, 1996; Maxwell, 1998; Knutson et al., 1999; Underwood \& Shapiro, 1999). Life history characters of numerous insects, in which males outnumber females, do not fulfill conditions necessary for selective pressure for the unequal sex ratio (West \& Sheldon, 2002). In such situation, a higher number of males is usually explained as a result of differences in mortality rates and energy allocation during maturation (Anholt, 1997; Stocks, 2001a). However, clear direct analyses of sex ratio in different developmental stages of non-social insects are still quite rare.

This paper presents the results of analyses of the adult sex ratio in wild and captive reared populations of the apollo butterfly (Parnassius apollo) in Pieniny National Park. Among many members of the genus Parnassius, males usually significantly outnumber females, with the sex ratio close to $2: 1$ (Konvička \& Kuras, 1999; Matter \& Roland, 2002). The same pattern is observed in other apollo butterfly populations (Fjellstad, 1996; Brommer \& Fred, 1999; Dankowá, 2002; Descimon, pers. commun.). However, there have been no attempts at explaining possible mechanisms of this phenomenon in this genus. Captive breeding of the apollo butterfly in Pieniny National Park, established as a part of the population recovery project, enabled comparisons of the sex ratio between the captive and wild populations.

\section{MATERIAL AND METHODS}

\section{Study site and population}

The populations were studied in the Polish part of the Pieniny Mts (Fig. 1) - a low (the highest peak Wysoka - $1050 \mathrm{~m}$ a.s.1.), calcareous mountain range. At least since the 1940s, a constant population decline has been observed (Adamski \& Witkowski, 1999a). In 1991, the population recovery program started. Supplementing the wild population with captive-bred individuals was one of the main parts of this program. Captive breeding was established in 1991, on the basis of local caterpillars collected in the field. Every year the majority of captive-bred butterflies have been marked with unique codes and released into the wild (Table 1).

\section{Data collecting}

The sex ratio among imagines in the captive-bred individuals was analyzed twice: before releasing them, and on the basis of subsequent recaptures of the marked individuals in the field. The same capture-mark-recapture method was used for moni-

TABLE 1. Numbers of individuals in the consecutive years of the recovery project.

\begin{tabular}{|c|c|c|c|c|c|c|}
\hline & \multicolumn{2}{|c|}{$\begin{array}{c}\text { Captive } \\
\text { individuals* } \\
\text { reared }\end{array}$} & \multirow{2}{*}{\multicolumn{2}{|c|}{$\begin{array}{c}\text { Captive indi- } \\
\text { viduals caught } \\
\text { after release } \\
\text { males females }\end{array}$}} & \multirow{2}{*}{\multicolumn{2}{|c|}{$\begin{array}{c}\text { Wild } \\
\text { individuals } \\
\text { males females }\end{array}$}} \\
\hline & males & females & & & & \\
\hline 1993 & $286(268)$ & $288(275)$ & 50 & 37 & 32 & 18 \\
\hline 1994 & $72(61)$ & $54(42)$ & 57 & 40 & 56 & 34 \\
\hline 1995 & $208(170)$ & $178(163)$ & 60 & 45 & 58 & 31 \\
\hline 1996 & $162(151)$ & $167(152)$ & 32 & 20 & 86 & 49 \\
\hline 1997 & $228(208)$ & $231(212)$ & 57 & 22 & 178 & 113 \\
\hline 1998 & $134(121)$ & $137(120)$ & 26 & 15 & 267 & 144 \\
\hline 1999 & $264(249)$ & $220(206)$ & 30 & 11 & 232 & 130 \\
\hline 2000 & $255(235)$ & $168(154)$ & 31 & 15 & 235 & 130 \\
\hline 2001 & $225(214)$ & $269(246)$ & 33 & 18 & 289 & 115 \\
\hline 2002 & $137(0)$ & $126(0)$ & 0 & 0 & 397 & 127 \\
\hline Total & $\begin{array}{r}1971 \\
(1677)\end{array}$ & $\begin{array}{r}1838 \\
(1570)\end{array}$ & 376 & 223 & 1830 & 891 \\
\hline
\end{tabular}

* - number of individuals introduced into the field are given in parentheses. 


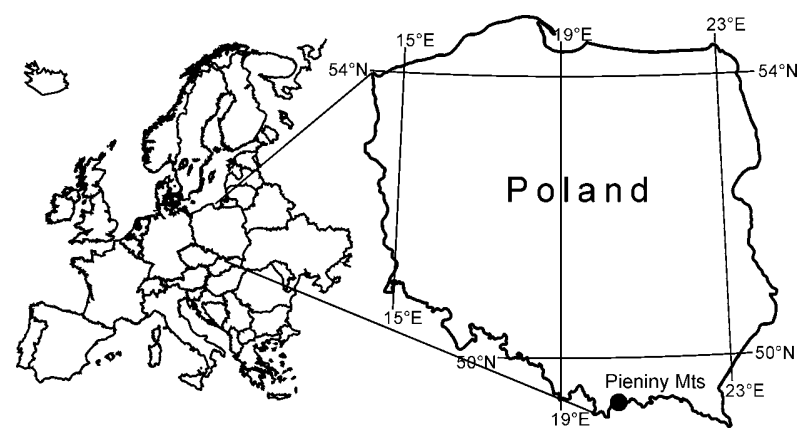

Fig 1. Location of the study area.

toring the wild population. In the period of imagines presence (from June to August), at each site the population was surveyed every two days. During the survey of the site butterflies were caught and the following information was recorded (Witkowski \& Adamski, 1996; Adamski \& Witkowski, 1999a):

- date, time and place of the capture;

- individual code (also caught wild individuals were marked with a unique code);

- sex of individual.

In 2002 the information on the activity of butterflies (flying or sitting) was also recorded.

Collected data was used for the estimation of the natural population size, which since 1996 has been fairly high, ranging between 660 in 1997 and 1500 in 2003 (Adamski \& Witkowski 1999a; Adamski et al., 2001).

To find possible sex related difference the time pattern of activity and microhabitat preference of males and females were compared.

Field studies enabled comparison of the sex ratio between the wild and the captive-bred population before and after releasing it into the wild. Datasets from 1993-2002 were included into the analyses (Adamski \& Witkowski, 1999a). The number of males and females in wild and captive reared populations were compared beetwen the groups. Also comparison within the groups was carried out with the expected frequency of both sexes calculated for sex ratio $1: 1$. For each year, the sex ratio coefficient was calculated according to the formula:

$$
R=\frac{M}{F}
$$

where $\mathrm{M}$ is the number of males and $\mathrm{F}$ - the number of females recorded in the field.

Regression line between the adult sex ratio and the total number of wild individuals recorded each year was then determined. Lifespan of wild individuals was estimated using the number of the days between the first and the last record.

\section{RESULTS}

\section{Sex ratio}

In 1993-2002, a total of 3247 captive-bred individuals of the apollo butterfly were introduced into the field. During the period of population monitoring in the field 599 of these individuals were recaptured. In addition, 2721 wild individuals were caught and marked in the field. Numbers of individuals in each group are presented in Table 1.

The sex ratio among all the captive reared individuals was close to $1: 1\left(\mathrm{R}=1.07 ; \chi^{2}=2.1 ; \mathrm{df}=1 ; \mathrm{p}=0.147\right)$, likewise the sex ratio of the captive reared individuals introduced into the field $\left(\mathrm{R}=1.06 ; \chi^{2}=1.76 ; \mathrm{df}=1 ; \mathrm{p}=0.184\right)$

However, among the captive reared individuals, recaptured in the field, males significantly outnumber the females $(\mathrm{R}=1.69$; $\left.\chi^{2}=19.88 ; \mathrm{df}=1 ; \mathrm{p}<0.0001\right)$. The sex ratio was also significantly male-biased in the wild population $\left(\mathrm{R}=2.05 ; \chi^{2}=\right.$
167.02; df $=1 ; \mathrm{p}<0.0001)$. The difference between the sex ratio in the wild population and the captive reared individuals caught in the field was significant $\left(\chi^{2}=4.43 ; \mathrm{df}=1 ; \mathrm{p}=0.035\right)$.

\section{Activity and lifespan}

In 2002, when activity of individuals was recorded in the field, the majority of females were observed sitting, whereas males were usually flying (Table 2 ). This difference in behavior pattern was statistically significant $\left(\chi^{2}=113.05 ; \mathrm{df}=1 ; \mathrm{p}<\right.$ 0.0001).

TABLE 2. Comparison of the activity patterns of males and females.

\begin{tabular}{|c|c|c|}
\hline & flying & sitting \\
\hline Females & 54 & 128 \\
\hline Males & 579 & 230 \\
\hline
\end{tabular}

The daily pattern of the capturing was almost the same for the both sexes $\left(\chi^{2}=4.77 ; \mathrm{df}=11 ; \mathrm{p}<0.9429\right)$, as well as the microhabitats preferences $\left(\chi^{2}=0.82 ; \mathrm{df}=7 ; \mathrm{p}<0.9978\right)$ (Tables 3,4$)$.

TABLE 3. The time pattern of the caught of both sexes.

\begin{tabular}{ccc}
\hline & \multicolumn{2}{c}{ Number of observations } \\
\cline { 2 - 3 } & females & males \\
\hline Before 9:00 & 32 & 94 \\
9:00-11:00 & 486 & 1498 \\
11:00-13:00 & 632 & 2107 \\
13:00-15:00 & 246 & 761 \\
15:00-17:00 & 314 & 1014 \\
After 17:00 & 58 & 141 \\
\hline
\end{tabular}

TABLE 4. Numbers of observation in the different habitats.

\begin{tabular}{lcc}
\hline \multirow{2}{*}{ Type of the habitat } & \multicolumn{2}{c}{ Number of observations } \\
\cline { 2 - 3 } & females & males \\
\hline Stony debris & 518 & 1598 \\
Xerothermic grassland & 683 & 2231 \\
Mountain meadows & 544 & 1717 \\
Other & 23 & 69 \\
\hline
\end{tabular}

The average number of records of each individual was higher for males than for females $(U=283947.0 ; Z=-8.84 ; p<$ $0.0001)$, the majority of the females was recorded only once, wheras median number of the records per males was 2. Due to extremely askew data distribution the statistical significance of the difference was checked using a non-parametric Mann Whitney "U" test (Sokal Rohlf, 1995).

Correlation between the sex ratio (R) and the number of marked wild individuals is presented in Fig. $2 \mathrm{a}\left(\mathrm{R}^{2}=0.402 ; \mathrm{p}=\right.$ 0.049 ). To avoid the possible artifacts generated by the presence of captive reared individuals, the same analysis was done separately for the Trzy Korony Massif - the biggest locality which was not supported by captive reared individuals. The results were almost the same $\left(\mathrm{R}^{2}=0.544 ; \mathrm{p}=0.014 ;\right.$ Fig $\left.2 b\right)$.

Significant difference in the time between the first and the last observation of males and females in the wild population of the apollo butterfly was also recorded: median for the females was 2 whereas for males $3(U=86027.0 ; Z=-5,20 ; p<00001)$; also in this case the "U" test was used due to extremely askew data distribution.

\section{DISCUSSION}

Lack of difference in the adult sex ratio recorded in the captive reared population suggests that the male-biased sex ratio observed in the wild population of the apollo butterfly is not an effect of significant differences in mortality between sexes during the maturation process. The captive breeding is conducted in the open volieras in the same area (less than $2 \mathrm{~km}$ 

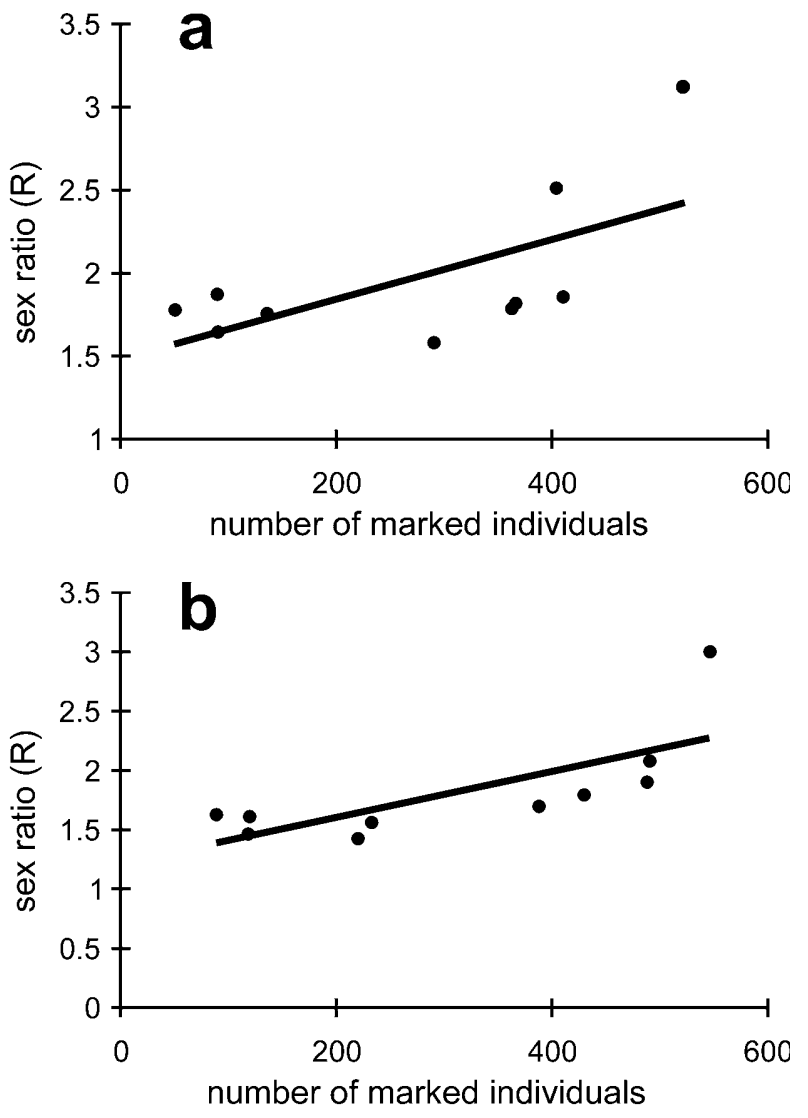

Fig. 2. Regression line between sex ratio and numbers of all individuals marked in the consecutive years. a - whole population, $b$ - Trzy Korony Massif - the main locality not supported by captive reared individuals.

from the nearest natural location). Therefore it is rather improbable, that the sex ratio in the wild was influenced by any weather factors not affecting the captive breeding. Higher number of males recorded in the field may therefore be either an effect of higher mortality rate in female imagines or an artifact caused by significantly lower detectability of females (Maxwell, 1998; Stoks, 2001b). In the studied population, field data strongly support the latter hypothesis. The most important source of this artifact is probably different behaviour of the sexes.

Flying apollo butterflies are very easy to spot, whereas dectectability of individuals sitting on the ground or plants is considerably lower due to cryptic coloration of the apollo forewings. White wings with black spots are very difficult to distinguish from calcareous debris or white inflorescences of plants. As a result, sitting individuals can only be detected within a distance of a few meters. Since females lay eggs on the ground or on lower parts of plants, they spend a considerable amount of time sitting low over the ground, whereas males fly for most of time (Table 2.).

The relationship between the observed sex ratio and differences in detectability of the sexes is supported by significant correlation between the number of marked individuals and the sex ratio (Fig. 2). A convincing explanation of this result is that researcher efforts are mainly concentrated on catching easily detected flying butterflies, whereas little time is spent on detection of sitting individuals.

Detectability, however, cannot be the only factor accounting for the male biased sex ratio recorded in the field, because it does not explain significant differences in the sex ratio between the wild population and captive individuals re-captured in the field. Less-pronounced male bias in captive-bred individuals recaptured in the field (Table 1), suggests that mortality between hatching from the pupae and the beginning of the mature stage can play an important role. Captive reared individuals were released into the wild approximately 1-2 days after they had hatched from pupae, when their wings were fully stretched and dried, therefore they were able to fly immediately. Wild individuals spend few hours stretching and drying their wings after hatching. Since this process is the same for both sexes, it should not have any effect upon the sex ratio among imagines. However, data from the captive breeding shows that serious deformations of the wings, connected with the process of hatching from the pupae and stretching the wings are approximately twice more frequent among females than among males (Adamski \& Witkowski, 1999b). Although no comparative field data is available, it is very likely that the same pattern occurs in the wild population. Moreover, it is probable that in a more unpredictable, "wild" environment, where factors which could disturb the processes of hatching and wing stretching are more likely than in captive breeding, the ratio of such phenodeviants may be also higher. Because individuals with deformed wings are undoubtedly less effective in avoiding predation, the difference in the frequency of wing deformation between the sexes may directly affect the sex ratio recorded in the population (Adamski \& Witkowski, 1999b).

A difference in lifespan between the sexes of the wild population recorded in the field may be another factor responsible for male biased sex ratio. The time span between the first and the last observation is significantly shorter for females than for males. It is not certain, however, at what degree this difference reflects an actual difference in survival of the sexes. As a result of poorer detectability, the number of recaptures per female is smaller in comparison with males. Generally, low probability of catching results in a large fraction of individuals caught only once, independent of the real abundance (Seber, 1882; White et al., 1982). Therefore, if there are significant differences in detectability between the sexes, the accuracy of lifespan estimation based on the mark-capture-recapture analysis is different for each sex. Unfortunately, the field data on lifespan of the apollo butterfly cannot be compared with data for captive-bred individuals which were not released into the wild, since they were not individually marked.

The presented results show that even such basic population structure as the sex ratio may be distorted by the sex related differences in the detectability. These differences are important particularly during the construction of PVA models (Brook et al., 2000), so knowledge of the possible source of an artifact may be useful for avoiding inappropriate models and conclusions.

\section{CONCLUSION}

The recorded male-biased sex ratio in the Pieninian population of the apollo butterfly is at least partially an artifact caused by more cryptic behavior of females. There are, however, some arguments suggesting that the described phenomenon is also connected with higher sensitivity of females to anomalies in the process of the stretching the wings just after eclosion. The influence of both these factors cannot, however, be precisely measured because it may differ between particular years due to differences in population abundance and environmental factors determining the conditions during hatching from pupae and stretching the wings. Anyway, there can be no doubt that where substantial sex related differences in the behaviour occur, any measured sex ratio may be significantly distored. 
ACKNOWLEDGEMENTS. The author would like to thank Z.J Witkowski, A. Kosior and P. Płonka for co-operation in collecting field data within the confines of apollo butterfly recovery project. Special thanks are due to B. Kozik and T. Oleś for making the captive breeding data available.

\section{REFERENCES}

ADAMSKi P. \& WitKowsKi Z. 1999a: Monitoring of local population of the apollo butterfly in the Pieniny Mountains as an example of LTER. In Bijok P. \& Prus M. (eds): Long Term Ecological Research. Examples, Methods, Perspectives for Central Europe. Proc. I LTER Reg. Workshop, September 1999, Madralin (Warsaw), Poland. US LTER Network Office, Dziekanów Leśny, pp. 137-141.

Adamski P. \& Witkowski Z. 1999b: Wing deformation in isolated Carpathian population of Parnasius apollo (Papilionidae: Parnassiinae). Nota Lepid. 22(1): 67-73

Adamski P., Witkowski Z., Kosior A. \& Oleś T. 2002: Ten years of restitution of Apollo butterfly in Pieniny National Park - analysis of the projeckt effectiveness. In Karwowski K. (ed.): Badania Naukowe $w$ Pieninach 2002. [Scientific Research in the Pieniny Mts 2002.] Pieniny National Park, Krościenko n/D, 21 pp. (in Polish).

AnHolt B.R. 1997: Sexual size dimorphism and sex-specific survival in adults of the damselfly Lestes disjunctus. Ecol. Entomol. 22: 127-132.

Brommer J.E. \& Fred M.S. 1999: Movement of the Apollo butterfly Parnassius apollo related to host plant and nectar plant patches. Ecol. Entomol. 24: 125-131.

Brook B.W., Burgman M.A. \& Frankham R. 2000: Differences and congruencies between PVA packages: the importance of sex ratio for predictions of extinction risk Conserv. Ecol. 4 (1), 6. [online] URL: http://www.consecol.org/vol4/iss 1/art6

Caughley G. \& GunN A. 1996: Conservation Biology in Theory and Practice. Blackwell Science, Oxford, pp. 163-220.

DANKovÁ K. 2002: Apollo butterfly (Parnassius apollo) in the Pieniny Mts. In Karwowski K. (ed.): Badania Naukowe w Pieninach 2002. [Scientific Research in the Pieniny Mts 2002.] Pieniny National Park, Krościenko n/D, 23 pp. (in Slovak).

FJELLSTAD W. 1996: Flight patterns and population structure of Parnassius apollo, in a Norwegian cultural landscape. In Pulin A. (ed.): Butterfly Conservation. 2nd Int. Symp., University of Warwick, September. Book of Abstracts. University of Warwick, p. 33.

KnUtson R.L., KwIlosz J.R. \& GRUndel R. 1999: Movement patterns and population characteristics of the Karner blue but- terfly (Lycaeides melissa samuelis) at Indiana Dunes National Lakeshore. Nat. Area J. 19: 109-120.

KONVIČKa M. \& KuRAS T. 1999: Population structure, behaviour and selection of oviposition sites of an endangered butterfly, Parnassius mnemosynae in Litovelské Pomoraví, Czech Republic. J. Insect Conserv. 3: 211-223.

Matter S.F. \& Roland J. 2002: An experimental examination of the effects of habitat quality on the dispersal and local abundance of the butterfly Parnassius smintheus. Ecol. Entomol. 27: 308-316.

Maxwell M.R. 1998: Seasonal adult sex ratio shift in the praying mantid Iris oratoria (Mantodea: Mantidae). Environ. Entomol. 27: 318-323.

McCarthy M.A., Franklin D.C. \& Burgman M.A. 1994: The importance of demographic uncertainty: an example from the helmet honeyeater Lichenostomus melanops cassidix. Biol. Conserv. 67: 135-142.

Reed D.H., O’Grady J.J., Brook B.W., Ballou J.D. \& FRANKHAM R. 2003: Estimates of minimum viable population sizes for vertebrates and factors influencing those estimates. Biol. Conserv. 113: 23-34.

Schtickzelle N., Baguette M. \& Le Boulenge E. 2003: Modelling insect demography from capture-recapture data: comparison between the constrained linear models and the Jolly-Seber analytical method. Can. Entomol. 135: 313-323.

Seber G.A.F. 1982: The Estimation of Animal Abundance and Related Parameters. Charles Griffin, London, pp. 161-230.

Stокs R. 2001a: What causes male-biased sex ratios in mature damselfly populations? Ecol. Entomol. 26: 188-197.

Stокs R. 2001b: Male-biased sex ratios in mature damselfly populations: real or artefact? Ecol. Entomol. 26: 181-187.

TAKAMURA K. 1996: Changes in sex ratio of chironomid imagines from rice field waters. Arch. Hydrobiol. 135: 413-421.

Underwood D.L.A. \& Shapiro A.M. 1999: A male-biased primary sex ratio and larval mortality in Eucheira socialis (Lepidoptera: Pieridae). Evol. Ecol. Res. 1: 703-717.

West S.A. \& Sheldon B.C. 2002: Constraints in the evolution of sex ratio adjustment. Science 295: 1685-1688.

White G.C., Anderson D.R., Burnham K.P. \& Otis D.L. 1982: Capture-Recapture and Removal Methods for Sampling Closed Populations. Los Alamos Nat. Lab., Los Alamos, New Mexico, pp. 98-146.

WitKowski Z. \& ADAMSKI P. 1996: Decline and rehabilitation of the Apollo butterfly Parnassius Apollo (Linnaeus 1758) in the Pieniny National Park. In Settele J., Margules C., Poschlod P. \& Henle K. (eds): Species Survival in Fragmented Landscapes. Kluwer, Dordrecht, Boston, London, pp. 7-14. 